\title{
PERAMALAN HARGA SAHAM DENGAN METODE LOGISTIC SMOOTH TRANSITION AUTOREGRESSIVE (LSTAR) \\ (Studi Kasus pada Harga Saham Mingguan PT. Bank Mandiri Tbk Periode 03 Januari 2011 sampai 24 Desember 2018)
}

\author{
Maria Odelia ${ }^{1}$, Di Asih I Maruddani ${ }^{2}$, Hasbi Yasin ${ }^{3}$ \\ 1,2,3 Departemen Statistika, Fakultas Sains dan Matematika, Universitas Diponegoro \\ mariaodelia@student.undip.ac.id
}

\begin{abstract}
Series such as financial and economic data do not always forma linear model, so a nonlinear model is needed. One of the popular nonlinear models is the Smooth Transition Autoregressive(STAR). STAR has two possible suitable transition function such as logistic and exponential that need to be test to find the appropriate transition function. The purpose of writing this thesis is to determine the LSTAR model, then use the model to predict the stock price of PT Bank Mandiri. This study uses the data of the weekly stock price of PT Bank Mandiii from the period of January 3,2011 to December 24, 2018 as ins ample data and the period of January 1, 2019 to December 30, 2019 as outsample data. The research procedure begins with modeling the data with the Autoregressive (AR) process, testing the linearity of the data, modeling with LSTAR, forecasting, and finally evaluating the results of forecasting. Evaluating the results of the forecasting of the weekly share price of PT Bank Mandiri with the STAR model results in the best nonlinear model LSTAR $(1,1)$. This model produces an highly accurate forecasting result with a value of symmetric Mean Square Error (sMAPE) to be $5.12 \%$.
\end{abstract}

Keywords: Nonlinear, Time Series, STAR, LSTAR.

\section{PENDAHULUAN}

Investasi kini mulai diminati oleh masyarakat Indonesia. Hal itu, dapat dilihat dari jumlah investor yang tumbuh sebesar 53,04\% yang terdiri dari investor saham, reksa dana, dan surat berharga negara (SBN) dengan investor lokal mencapai 98,97\% dan 1,03\% merupakan investor asing. Dari banyaknya kegiatan investasi di pasar modal, saham menjadi salah satu bentuk investasi yang banyak dipilih oleh investor. Saham merupakan sertifikat bukti kepemilikan sebuah perusahaan (Zubir, 2011). Hal tersebut dapat terlihat dari peningkatan jumlah investor saham dari 852.240 Single Investor Identification (SID) menjadi 1,10 juta (SID).

Harga saham akan mengalami pergerakan naik dan turun setiap harinya. Oleh sebab itu, saham sering kali dianggap salah satu investasi yang beresiko. Pergerakan harga saham yang tidak stabil menggambarkan kondisi pasar pada suatu saat dan menjadi indikator penting bagi para investor untuk menentukan apakah mereka akan menjual, menahan atau membeli satu atau beberapa saham sehingga dalam hal ini dibutuhkan metode untuk meramalkan harga saham tersebut. Harga saham berbentuk data runtun waktu (time series), sehingga untuk meramalkan harga saham dapat menggunakan metode runtun waktu. Metode runtun waktu yang sering digunakan dalam analisis runtun waktu adalah metode BoxJenkins. Model yang dihasilkan pada metode Box-Jenkins merupakan model linier, semantara fakta membuktikan bahwa ketergantungan runtun waktu terhadap informasi historis tidak selalu linear (Santoso, 2017). Jika asumsi linieritas tidak dipenuhi maka metode Box-Jenkins kurang sesuai, sehingga diperlukan model baru yang nonlinier untuk analisis data tersebut.

Salah satu metode nonlinier, yaitu Smooth Transition Autoregressive (STAR) yang diperkenalkan oleh Granger dan Terasvirta pada tahun 1993 yang merupakan perluasan dari 
model autoregressive untuk data waktu nonlinier. Terasvirta (1994) membagi tipe model STAR berdasarkan fungsi transisinya, yaitu Logistic Smooth Transition Autoregressive (LSTAR) apabila fungsi transisinya logistik dan Eksponential Smooth Transition Autoregressive (ESTAR) apabila fungsi transisinya eksponensial. Metode yang akan digunakan oleh penulis dalam penelitian ini adalah LSTAR. Hal tersebut dikarenakan data return Bank Mandiri yang digunakan dalam penelitian sesuai dengan fungsi logistik setelah diuji.

Tujuan yang ingin dicapai dalam penulisan ini, yaitu: menguji apakah fungsi transisi LSTAR sesuai untuk meramalkan return harga saham Bank Mandiri, menentukan model LSTAR untuk memodelkan return saham Bank Mandiri dan meramalkan data harga saham Bank Mandiri untuk bulan Januari sampai Desember 2019.

\section{TINJAUAN PUSTAKA}

\subsection{Return}

Campbell, et.al (1997) memberikan dua alasan utama megapa return lebih sering digunakan dalam analisis, yaitu pertama return merupakan ringkasan peluang investasi yang lengkap dan ringkas dan alasan yang kedua deret return lebih mudah untuk ditangani daripada deret harga karena memiliki sifat statistik yang lebih menarik seperti stasioneritas. Menurut Tsay (2010), return dirumuskan sebagai berikut:

$$
X_{t}=\ln \left(\frac{P_{t}}{P_{t-1}}\right)
$$

dengan $P_{t}$ merupakan harga saham pada waktu ke-t dan $P_{t-1}$ merupakan harga saham pada waktu ke-t-1.

\subsection{Analis is Runtun Waktu}

Runtun waktu merupakan serangkaian pengamatan suatu variabel yang diambil dan dicatat dari waktu ke waktu secara berurutan menurut urutan kejadian dengan interval waktu yang tetap (Wei, 2006).

\subsection{Stasioneritas}

Data runtun waktu memiliki syarat bahwa data harus dalam keadaan stasioner, yaitu tidak adanya perubahan kecendrungan dalam rata-rata (mean) dan perubahan varian. Stasioner data dalam varian dapat dilakukan dengan menggunakan transformasi Box-Cox plot. Jika nilai rounded value (lambda) bernilai satu maka data stasioner dalam varian tetapi jika nilai rounded value kurang dari satu maka perlu dilakukan proses transformasi. Stasioneritas dalam mean dengan menggunakan uji akar unit, yaitu uji Augmented Dickey Fuller (ADF), seperti berikut:

Hipotesis:

$\mathrm{H}_{0}: \phi=1$; (terdapat akar unit atau data tidak stasioner)

$\mathrm{H}_{1}: \phi<1$; (tidak terdapat akar unit atau data stasioner)

Taraf Sigifikansi: $\alpha$

Statistik Uji:

$$
\begin{aligned}
& A D F=t_{\text {ratio }}=\frac{\widehat{\phi}-1}{s e(\hat{\phi})} \\
& \operatorname{se}(\widehat{\phi})=\sqrt{\frac{1-\widehat{\phi}^{2}}{T}}
\end{aligned}
$$

$\widehat{\Phi}$ merupakan estimator dari $\Phi, s e(\widehat{\Phi})$ merupakan standar residual dari $\Phi$, dan T merupakan ukuran sampel.

Kriteria Penolakan:

$\mathrm{H}_{0}$ ditolak jika $\mathrm{t}_{\text {ratio }}>\mathrm{t}_{(\mathrm{n}, \alpha)}$ atau $p$-value $<\alpha$. 


\subsection{Indetifikasi Model $A R(p)$}

Pada tahap identifikasi model akan digunakan function auto.arima pada package forecast dalam bahasa pemrograman R. Penggunaan fungsi auto.arima dilakukan untuk mempermudah proses pemodelan ARIMA. Fungsi ini secara otomatis memilih model ARIMA menggunakan variasi algoritma Hyndman-Khandakar (Hyndman \& Khandakar, 2008), yang menggabungkan unit root test, minimalisasi AIC, dan MLE untuk mendapatkan model ARIMA. Menurut Van Dijk (1999), AIC dirumuskan sebagai berikut:

$A I C=T \ln \hat{\sigma}_{a}^{2}+2 k$

dengan $\hat{\sigma}_{a}^{2}=\sum_{t=1}^{T} \hat{a}_{t}^{2}$, T merupakan ukuran sampel, $\hat{a}_{t}^{2}$ merupakan residual dari estimasi model, dan $\mathrm{k}=\mathrm{p}+1$; $\mathrm{k}$ merupakan banyaknya parameter model

\subsection{Estimasi dan Pengujian Parameter AR(p)}

Menurut Wei (2006), bentuk umum model Autoregressive tingkat p (AR(p)), yaitu:

$$
X_{t}=\phi_{1} X_{t-1}+\phi_{2} X_{t-2}+\ldots+\phi_{p} X_{t-p}+a_{t}
$$

Dengan estimasi parameter AR dapat diperoleh dengan menggunakan metode kuadrat terkecil atau Least Square Method, yaitu dengan meminimumkan jumlah kuadrat residual berikut:

$$
\sum_{t=2}^{T} a_{t}^{2}=S S E=\sum_{t=2}^{T}\left(X_{t}-\phi_{1} X_{t-1}+\phi_{2} X_{t-2}+\ldots+\phi_{p} X_{t-p}\right)^{2}
$$

Dengan pengujian hipotesis sebagai berikut:

$\mathrm{H}_{0}: \phi_{j}=0$ (parameter tidak signifikan)

$\mathrm{H}_{1}: \phi_{j} \neq 0$ (parameter signifikan); untuk $\mathrm{j}=1,2, \ldots, \mathrm{p}$

Taraf Signifikansi: $\alpha$

Statistik Uji:

$$
\begin{aligned}
& t_{\text {hit }}=\frac{\widehat{\phi}_{j}}{s e\left(\widehat{\phi}_{j}\right)} ; s e(\widehat{\phi})=\sqrt{\frac{1-\widehat{\phi}_{j}^{2}}{T}} \\
& \operatorname{se}(\widehat{\phi})=\sqrt{\frac{1-\widehat{\phi}_{j}^{2}}{T}}
\end{aligned}
$$

Kriteria Penolakan:

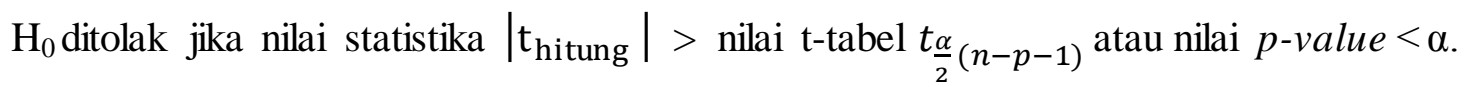

\subsection{Model Smooth Transition Autoregressive (STAR)}

Menurut Van Dijk (1999), model STAR (p,d) dimodelkan sebagai berikut:

$$
\begin{aligned}
X_{t}= & \phi_{1,0}+\phi_{1,1} X_{t-1}+\cdots+\phi_{1, p} X_{t-p}\left(1-G\left(s_{t} ; \gamma, c\right)\right)+\phi_{2,0}+\phi_{2,1} X_{t-1} \\
& +\ldots+\phi_{2, p} X_{t-p} G\left(s_{t} ; \gamma, c\right)+\varepsilon_{t}
\end{aligned}
$$

atau

$$
X_{t}=\boldsymbol{\phi}_{1}^{\prime} \boldsymbol{Z}_{\boldsymbol{t}}\left(1-G\left(s_{t} ; \gamma, c\right)\right)+\boldsymbol{\phi}_{2}^{\prime} \boldsymbol{Z}_{\boldsymbol{t}} G\left(s_{t} ; \gamma, c\right)+\varepsilon_{t}
$$

dengan

$\boldsymbol{Z}_{\boldsymbol{t}}=\left[1, \widetilde{\boldsymbol{X}}_{t}^{\prime}\right]^{\prime}$ dengan $\widetilde{\boldsymbol{X}}_{\boldsymbol{t}}=\left[X_{t-1}, \ldots, X_{t-p}\right]^{\prime}: \log$ return pada saat periode ke-t

$\phi_{1}=\left[\phi_{1,0}, \phi_{1,1}, \phi_{1,2}, \ldots, \phi_{1, p}\right]^{\prime}$ dan $\phi_{2}=\left[\phi_{2,0}, \phi_{2,1}, \phi_{2,2}, \ldots, \phi_{2, p}\right]^{\prime}$

Keterangan

$s_{t}=X_{t-d}$ : variabel transisi mengikuti besar orde p pada model AR (p) dengan $1 \leq d \leq p$

$G\left(s_{t} ; \gamma, c\right)$ : fungsi transisi bernilai $[0,1]$

c : nilai threshold atau parameter lokasi

$\gamma \quad$ : slope atau parameter pemulusan (smoothing)

$\varepsilon_{t} \quad:$ nilai residual model STAR 
Menurut Van Dijk (1999), model STAR terbagi menjadi dua tipe berdasarkan fungsi transisinya, yaitu fungsi transisi eksponensial yang disebut Exponential Smooth Transition Autoregressive (ESTAR) dan fungsi transisi logistik yang disebut Logistic Smooth Transition Autoregressive (LSTAR).

\subsection{Pengujian Linie ritas}

Pengujian linieritas dapat dilakukan dengan menggunakan kelompok uji Lagrange Multiplier (LM), yaitu $\mathrm{LM}_{3}$. Statistik $\mathrm{LM}_{3}$ dapat diperoleh dengan cara:

1. Menghitung residual $\left(\hat{a}_{t}\right)$ dan jumlah kuadrat residual pada model AR

$$
S S R_{0}=\sum_{t=1}^{T} \hat{a}_{t}^{2}
$$

2. Menduga regresi bantuan (auxiliary regression) $\hat{a}_{t}^{2}$ terhadap $\left(1, \widetilde{\boldsymbol{X}}_{t}\right)$ dan $\widetilde{\boldsymbol{X}}_{t} s_{t}^{i} ; i=$ $1,2,3, \ldots$

$$
\hat{a}_{t}=\beta_{0,0}+\boldsymbol{\beta}_{\mathbf{0}}^{\prime} \widetilde{\boldsymbol{X}}_{\boldsymbol{t}}+\boldsymbol{\beta}_{\mathbf{1}}^{\prime} \widetilde{\boldsymbol{X}}_{\boldsymbol{t}} s_{t}+\boldsymbol{\beta}_{\mathbf{2}}^{\prime} \widetilde{\boldsymbol{X}}_{\boldsymbol{t}} s_{t}^{2}+\boldsymbol{\beta}_{\mathbf{3}}^{\prime} \widetilde{\boldsymbol{X}}_{\boldsymbol{t}} s_{t}^{3}+e_{t}
$$

Kemudian menghitung jumlah residual kuadrat dari regresi bantuan

$$
S S R_{1}=\sum_{t=1}^{T} \hat{e}_{t}^{2}
$$

3. Dengan pengujian sebagai berikut:

Hipotesis

$$
H_{0}: \phi_{1, i}=\phi_{2, i} \text { (model linier) }
$$

$H_{1}: \phi_{1, i} \neq \phi_{2, i} ;$ dengan minimal satu $\mathrm{i} \in\{1,2, \ldots, p\}$ (model nonlinier)

Taraf Signifikansi: $\alpha$

Statistik Uji:

$$
L M_{3}=T \frac{\left(S S E_{0}-S S E_{1}\right)}{S S E_{0}}
$$

Keterangan:

$\mathrm{SSE}_{0}$ merupakan jumlah kuadrat residual model $\mathrm{AR}(\mathrm{p})$ dan $\mathrm{SSE}_{1}$ merupakan jumlah kuadrat residual model regresi bantu.

Kriteria Penolakan:

$$
\mathrm{H}_{0} \text { ditolak jika nilai statistika } L M_{3}>\chi_{3(p+1)}^{2}
$$

\subsection{Fungsi Transisi}

\subsubsection{Fungsi Transisi Logistik Pada Model LSTAR}

Menuru Terasvirta (1994), fungsi transisi logistik adalah sebagai berikut:

$$
G\left(s_{t} ; \gamma, c\right)=\frac{1}{1+\exp \left(-\gamma\left(s_{t}-c\right)\right)}, \gamma>0
$$

Dari persamaan di atas dapat diperoleh model LSTAR berikut:

$$
X_{t}=\boldsymbol{\phi}_{1} \boldsymbol{Z}_{\boldsymbol{t}}\left(1-\left(\frac{1}{1+\exp \left(-\gamma\left(s_{t}-c\right)\right)}\right)+\boldsymbol{\phi}_{\mathbf{2}} \boldsymbol{Z}_{\boldsymbol{t}}\left(\frac{1}{1+\exp \left(-\gamma\left(s_{t}-c\right)\right)}\right)+\varepsilon_{t}\right.
$$

\subsubsection{Fungsi Transisi Eksponensial Pada Model ESTAR}

Menuru Terasvirta (1994), fungsi transisi eksponensial adalah sebagai berikut:

$$
G\left(s_{t} ; \gamma, c\right)=1-\exp \left(-\gamma\left(s_{t}-c\right)^{2}\right), \gamma>0
$$

Dari persamaan di atas dapat diperoleh model ESTAR berikut:

$$
X_{t}=\phi_{1} Z_{t}\left(1-\left(1-\exp \left(-\gamma\left(s_{t}-c\right)^{2}\right)+\phi_{2} Z_{t}\left(1-\exp \left(-\gamma\left(s_{t}-c\right)^{2}\right)+\varepsilon_{t}\right.\right.\right.
$$

\subsubsection{Pengujian Fungsi Transisi}

Pemilihan fungsi transisi $G\left(s_{t} ; \gamma, c\right)$ dilakukan dengan menguji urutan hipotesis dari regresi bantu sebagai berikut:

Untuk $\mathrm{H}_{0}$ :

(i) $H_{0,1}: \beta_{3}=0$; untuk $\mathrm{j} \in\{0,1,2, \ldots, p\}$

(ii) $H_{0,2}: \beta_{2}=0 \mid \beta_{3}=0 ;$ untuk $\mathrm{j} \in\{0,1,2, \ldots, p\}$ 
Untuk $\mathrm{H}_{1}$ :

(iii) $H_{0,3}: \beta_{1}=0 \mid \beta_{3}=\beta_{2}=0$; untuk $\mathrm{j} \in\{0,1,2, \ldots, p\}$

(i) $H_{1,1}: \beta_{3} \neq 0 ;$ untuk $\mathrm{j} \in\{0,1,2, \ldots, p\}$

(ii) $H_{1,2}: \beta_{2} \neq 0 \mid \beta_{3}=0$; untuk $\mathrm{j} \in\{0,1,2, \ldots, p\}$

(iii) $H_{1,3}: \beta_{1} \neq 0 \mid \beta_{3}=\beta_{2}=0$; untuk $\mathrm{j} \in\{0,1,2, \ldots, p\}$

Dengan ketentuan:

(i) Jika $\beta_{3} \neq 0$, maka model adalah LSTAR

(ii) Jika $\beta_{3}=0$, tetapi $\beta_{2} \neq 0$, maka model adalah ESTAR

(iii) Jika $\beta_{3}=0$ dan $\beta_{2}=0$, tetapi $\beta_{1} \neq 0$, maka model adalah LSTAR dan jika $\beta_{1}=0$ maka model adalah ESTAR.

Statistik Uji:

$$
\begin{aligned}
& t=\frac{\widehat{\beta_{1, j}}}{s e\left(\widetilde{\beta_{1, j}}\right)} \\
& \text { se }\left(\widehat{\beta_{1, \mathrm{j}}}\right)=\sqrt{\sigma^{2} G_{n n}} ; n=i \times p+j+1 \\
& \sigma^{2}=\frac{S S E}{T-k-1}
\end{aligned}
$$

Keterangan: $\widehat{\beta_{1, j}}$ merupakan penduga bagi $\beta_{\mathrm{i}, \mathrm{j}}$; untuk $\mathrm{i} \in\{0,1,2,3\}$; untuk $\mathrm{j} \in\{0,1,2, \ldots, p\}$, se $\left(\widehat{\beta_{1, \mathrm{j}}}\right)$ merupakan standar residual dari koefisien regresi $\widehat{\beta_{1, \mathrm{j}}}, \sigma^{2}$ merupakan varian dari residual model regresi bantu, $S S E=\sum_{t=1}^{T} \hat{e}_{t}^{2}$ merupakan jumlah kuadrat residual regresi bantu, $G_{n n}$ merupakan elemen dari diagonal utama matriks $\left(\mathbf{x}^{\prime} \mathbf{x}\right)^{\mathbf{- 1}}$, dan p merupakan orde dari model $\mathrm{AR}(\mathrm{p})$.

Kriteria Penolakan:

$\mathrm{H}_{0}$ ditolak jika nilai statistika $\mid$ thitung $\mid>t_{\frac{\alpha}{2}}$,dbg atau nilai $p$-value $<\alpha$.

\subsection{Estimasi Parame te r Model LSTAR}

Dijk (1999) menggunakan metode Nonlinear Least Square (NLS) untuk mengestimasi parameter. Estimasi parameter pada metode NLS ditentukan dengan meminimumkan jumlah kuadrat residu yang didefinisikan sebagai: dengan

$$
\hat{\theta}=\arg \min \mathcal{Q}_{T}(\theta)=\arg \min \sum_{t=1}^{T}\left(X_{t}-F\left(Z_{t}, \theta\right)\right)^{2}
$$

$$
F\left(Z_{t}, \theta\right)=\boldsymbol{\phi}_{\mathbf{1}}^{\prime} \boldsymbol{Z}_{\boldsymbol{t}}\left(1-G\left(s_{t} ; \gamma, c\right)\right)+\boldsymbol{\phi}_{\mathbf{2}}^{\prime} \boldsymbol{Z}_{\boldsymbol{t}} G\left(s_{t} ; \gamma, c\right)
$$

Proses pencarian nilai parameter pada metode NLS ini dilakukan dengan menggunakan metode numerik yaitu metode Gauss-Newton untuk melakukan estimasi secara iterasi.

\subsection{Asumsi White-Noise Residual}

\subsubsection{Asumsi Autokorelasi Residual}

Menurut Wei (2006), uji autokorelasi dapat dilakukan menggunakan uji hipotesis Ljung Box-Pierce, sebagai berikut:

$\mathrm{H}_{0}: \rho_{1}=\rho_{2}=\ldots=\rho_{m}=0$ (tidak ada korelasi antar lag)

$\mathrm{H}_{1}$ : paling sedikit ada satu $\rho_{k} \neq 0$ dengan $\mathrm{k}=1,2,3, \ldots, \mathrm{m}$ (terdapat korelasi antar lag)

Taraf Signifikansi: $\alpha$

Statistik Uji:

$$
\mathcal{Q}_{k}=T(T+2) \sum_{k-1}^{m} \frac{\widehat{\rho}_{k}^{2}}{T-k}
$$

Keterangan: $\hat{\rho}_{k}$ merupakan ACF residual pada lag ke k, dan m merupakan maksimum lag. Kriteria Penolakan:

$$
\mathrm{H}_{0} \text { ditolak jika nilai statistika } Q_{\text {hitung }}>\chi_{(\alpha, d f)}^{2} \text { atau } p \text {-value }<\alpha
$$

\subsubsection{Asumsi Heteroskedastisitas Residual}


Uji Lagrange Multiplier (LM) merupakan suatu uji terhadap keberadaan unsur heteroskedastisitas untuk mendeteksi adanya efek ARCH/GARCH. Hipotesis pengujian yang digunakan adalah sebagai berikut:

$\mathrm{H}_{0}: \alpha_{1}=\alpha_{2}=\ldots=\alpha_{m}=0$ (tidak ada efek ARCH/GARCH dalam residual sampai lag ke-m)

$\mathrm{H}_{1}$ : minimal ada satu nilai $\alpha_{i} \neq 0, \mathrm{i}=1,2, \ldots, \mathrm{m}$ (ada efek ARCH/GARCH dalam residual sampai lag ke-m)

Taraf Signifikansi: $\alpha$

Statistik Uji:

$$
\begin{aligned}
& L M=T R^{2}-\chi_{m}^{2} \\
& R^{2}=\frac{S S R}{S S T}=\frac{\sum_{t=1}^{m}\left(\widehat{a_{t}^{2}}-\overline{a_{t}^{2}}\right)^{2}}{\sum_{t=1}^{m}\left(a_{t}^{2}-\bar{a}_{t}^{2}\right)^{2}}
\end{aligned}
$$

Kriteria Penolakan:

$\mathrm{H}_{0}$ ditolak jika nilai statistika $L M>\chi_{(m)}^{2}$ atau $p$-value $<\alpha$

\subsubsection{Asumsi Normalitas Residual}

Pengujian yang digunakan untuk mengetahui apakah residual berdistribusi normal adalah dengan menggunakan Uji Kolmogorov-Smirnov. Hipotesis pengujian yang digunakan adalah sebagai berikut:

$\mathrm{H}_{0}$ : Residual berdistribusi normal

$\mathrm{H}_{1}$ : Residual tidak berdistribusi normal

Taraf Signifikansi: $\alpha$

Statistik Uji:

$$
D=\sup \left|S(x)-F_{0}(x)\right|
$$

Kriteria Penolakan:

$\mathrm{H}_{0}$ ditolak jika nilai statistika $D>W_{(1-\alpha), n}$ atau $p$-value $<\alpha$

\subsection{Peramalan dan Evaluasi Hasil Pe ramalan}

Evaluasi hasil peramalan bertujuan untuk mengevaluasi kualitas dari hasil peramalan model runtun waktu. Ukuran yang akan digunakan untuk evaluasi peramalan dalam penelitian ini adalah symmetric Mean Absolute Percentage Error (sMAPE). Menurut Chen, et.al (2017), sMAPE dirumuskan sebagai berikut:

$$
s M A P E=\frac{2}{n}\left(\sum_{t=1}^{n} \frac{\left|\hat{P}_{t}-P_{t}\right|}{\left|P_{t}\right|+\left|\hat{P}_{t}\right|}\right) \times 100 \%
$$

Dengan kriteria pengujian :

Tabel 1. Kriteria Peramalan sMAPE

\begin{tabular}{cc}
\hline Nilai sMAPE & Ketepatan Peramalan \\
\hline$<10 \%$ & Sangat Baik \\
$10 \%-20 \%$ & Baik \\
$20 \%-50 \%$ & Cukup Baik \\
$>50 \%$ & Buruk \\
\hline
\end{tabular}

\section{METODE PENELITIAN}

\subsection{Sumber Data}

Data yang digunakan pada penelitian ini adalah data sekunder mengenai data harga saham mingguan PT Bank Mandiri (Persero) Tbk, yang diambil dari alamat web http:/finance.yahoo.com periode 03 Januari 2011 sampai 24 Desember 2018 sebagai data insample dan periode 01 Januari 2019 sampai 30 Desember 2019 sebagai data outsample. 


\subsection{Metode Analisis}

Software yang digunakan pada penelitian ini adalah Ms. Excel 2016 dan Rstudio dengan tahapan analisis sebagai berikut:

1. Menghitung nilai return dari harga saham PT Bank Mandiri (Persero) Tbk

2. Melakukan uji stasioneritas data return

3. Mengidentifikasi model runtun waktu stasioner

4. Melakukan estimasi parameter AR (p)

5. Pemilihan model terbaik AR (p)

6. Orde model AR yang terbentuk akan digunakan sebagai variabel transisi pada pengujian linieritas dan model STAR

7. Melakukan uji linieritas model AR(p) dengan menggunakan regresi bantu

8. Menguji apakah fungsi transisi LSTAR(p) cocok untuk digunakan dalam memodelkan return saham PT Bank Mandiri (Persero) Tbk dengan regresi bantu

9. Mengestimasi model LSTAR(p)

10. Memodelkan LSTAR(p)

11. Melakukan uji asumsi White-Noise residual model LSTAR(p)

12. Meramalkan nilai return saham PT Bank Mandiri (Persero) Tbk menggunakan model LSTAR(p) untuk bulan Januari sampai Desember 2019

13. Merubah nilai ramalan return menjadi harga saham untuk mendapatkan ramalan harga saham PT Bank Mandiri (Persero) Tbk untuk bulan Januari sampai Desember 2019

14. Mencari indikasi presentase kesalahan hasil peramalan dengan menggunakan sMAPE

\section{HASIL DAN PEMBAHASAN}

\subsection{Deskripsi Data}

Pergerakkan harga saham PT. Bank Mandiri dapat terlihat dari Gambar 1 yang menampilkan plot dari harga saham PT. Bank Mandiri.

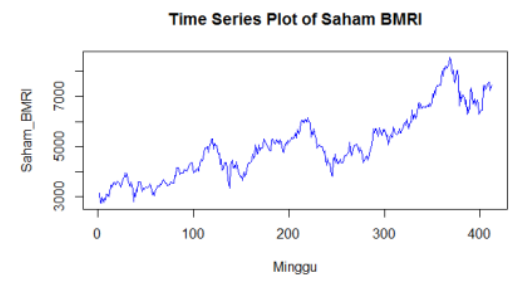

Gambar 1. Grafik Harga Saham PT Bank Mandiri (Persero) Tbk

Dari Gambar 1 dapat terlihat bahwa harga saham PT Bank Mandiri periode 03 Januari 2011 sampai 24 Desember 2018 tidak stasioner dan mengalami trend naik. Harga saham terkecil, yaitu 2753 dan harga saham tertinggi, yaitu 8550 dengan rata-ratanya, yaitu 5045 .

\subsection{Return}

Pergerakkan keuntungan dan kerugian dari saham PT. Bank Mandiri dapat terlihat dari Gambar 2 yang menampilkan plot dari return saham PT. Bank Mandiri.

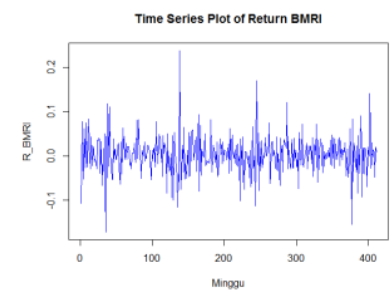


Dari Gambar 2 terlihat bahwa nilai return sudah stasioner, secara formal indikasi bahwa data sudah stasioner dapat diuji dengan uji Augmented Dickey Fuller (ADF).

\subsection{Stasione ritas}

Uji stasioneritas dalam varian menggunakan Transformasi Box-Cox berikut :

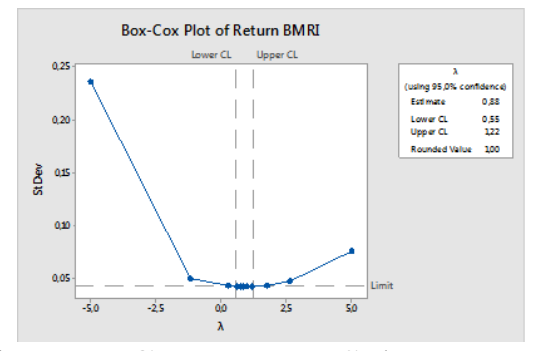

Gambar 3. Plot Box-Cox Return Saham PT. Bank Mandiri

Berdasarkan gambar 3 diperoleh nilai rounded value sebesar 1, artinya data return saham sudah stasioner dalam varian. Uji stasioner dalam mean akan diuji menggunakan uji ADF. Berdasarkan uji ADF diperoleh nilai statistik uji dengan menggunakan $\alpha$ sebesar $5 \%$ yaitu, nilai tratio $=-6,9166$ dengan $p$-value $=0,01$. Dari hasil tersebut dapat disimpulkan bahwa nilai $p$-value uji ADF lebih kecil dari $\alpha$ yang artinya menolak $\mathrm{H}_{0}$ yaitu tidak terdapat akar unit atau data stasioner.

\subsection{Identifikasi Model, Estimasi dan Pengujian Parameter Model AR}

Identifikasi model dilakukan dengan menggunakan menggunakan function auto.arima yang menghasilkan model terbaik dengan AIC terkecil, yaitu AR (1). Selanjutnya akan dilakukan dilakukan estimasi terhadap parameter model AR(1) dengan menggunakan metode Ordinary Least Square (OLS).

Tabel 2. Estimasi Parameter Model AR(1)

\begin{tabular}{cccccc}
\hline Model & AIC & Koefisien & t-hitung & Probabilitas & Uji Signifikan \\
\hline AR(1) & $-1438,39$ & $-0,169315$ & 3,45510 & 0,0005425 & Signifikan \\
\hline
\end{tabular}

Dari hasil diatas maka didapat variabel transisi yang akan digunakan pada model STAR diperoleh berdasarkan orde model AR (1), sehingga variabel transisi dalam model STAR adalah $s_{t}=X_{t-1}$.

\subsection{Uji Linie ritas}

Asumsi linieritas diuji menggunakan Lagrange Multiplier (LM). Pada perhitungan $\mathrm{LM}_{3}$ diperlukan model regresi bantu. Model regresi bantu diestimasi menggunakan metode Ordinary Least Square (OLS). Berikut estimasi model regresi bantu dengan variabel transisi $s_{t}=X_{t-1}$ :

Tabel 3. Estimasi Model Regresi Bantu dengan Variabel Transisi $s_{t}=X_{t-1}$

\begin{tabular}{crrr} 
Parameter & \multicolumn{1}{c}{ Koefisien } & \multicolumn{1}{c}{ t_hitung } & \multicolumn{1}{c}{$\boldsymbol{P r}(>\mid \mathbf{t})$} \\
\hline Intercept & 0,004456 & 1,839 & 0,06662 \\
$\beta_{0,1}$ & 0,040565 & 0,605 & 0,54567 \\
$\beta_{1,1}$ & $-2,065241$ & $-2,030$ & 0,04298 \\
$\beta_{2,1}$ & $-8,911166$ & $-1,733$ & 0,08385
\end{tabular}




\begin{tabular}{crr}
$\beta_{3,1} \quad 101,193471$ & 3,046 & 0,00247 \\
\hline Sum SquareResidual & 0,6857568 \\
\hline
\end{tabular}

Berdasarkan uji $\mathrm{LM}_{3}$ dengan menggunakan $\alpha$ sebesar 5\% diperoleh nilai statistik uji untuk $\mathrm{LM}_{3}$, yaitu 13,25196 dengan nilai $p$-value $=0,03821511$ dan nilai tabel Chi-Square $=$ 12,597, dari hasil tersebut dapat disimpulkan bahwa nilai statistik $\mathrm{LM}_{3}$ lebih besar dari nilai tabel Chi-Square yang artinya tolak $\mathrm{H}_{0}$ sehingga model nonlinier.

\subsection{Pengujian Fungsi Transisi}

Setelah diketahui bahwa model yang terbentuk adalah nonlinier maka selanjutnya akan dilakukan pengujian fungsi transisi. Pengujian fungsi transisi dilakukan dengan menguji signifikansi terhadap $\beta$. Berdasarkan Tabel 2 probabilitas $\beta_{3,1}=0,00246$ lebih kecil dari pada nilai $\alpha=0,05$ yang berarti terima $\mathrm{H}_{0}$ sehingga fungsi transisi yang akan digunakan adalah fungsi transisi logistik.

\subsection{Model LSTAR}

Hasil estimasi model LSTAR $(1,1)$ dengan menggunakan metode Nonlinier Least Square (NLS) yang didekati dengan iterasi Gauss Newton adalah sebagai berikut:

Tabel 4. Hasil Estimasi Model LSTAR (1,1)

\begin{tabular}{crrr}
\hline Parameter & \multicolumn{1}{c}{ Koefisien } & \multicolumn{1}{c}{ t_hitung } & \multicolumn{1}{c}{ Probabilitas } \\
\hline$\phi_{1,1}$ & $-1,781118$ & $-32,6599$ & $<2 \mathrm{e}-16$ \\
$\phi_{2,1}$ & 3,275201 & 0,0036 & 0,9971 \\
$\gamma$ & 0,999998 & 0,0208 & 0,9834 \\
$c$ & 0,046558 & 0,0582 & 0,9536 \\
\hline
\end{tabular}

Sehingga model LSTAR $(1,1)$ yang terbentuk adalah:

$$
\begin{array}{r}
X_{t}=-1,781118 X_{t-1}\left(1-\left(\frac{1}{1+\mathrm{e}^{-0,999998\left(X_{t-1}-0,046558\right)}}\right)\right) \\
+3,275201 X_{t-1}\left(\frac{1}{1+\mathrm{e}^{-0,999998\left(X_{t-1}-0,046558\right)}}\right)+\varepsilon_{t}
\end{array}
$$

\subsection{Uji Asumsi White-Noise Residual LSTAR $(1,1)$}

\subsubsection{Asumsi Autokorelasi Residual LSTAR $(1,1)$}

Pada penelitian ini untuk mengetahui ada tidaknya autokorelasi pada residual dapat diuji menggunakan uji Ljung Box-Pierce. Berikut hasil uji autokorelasi menggunakan uji Ljung Box-Pierce:

Tabel 5. Uji Autokorelasi Residual Model LSTAR $(1,1)$

\begin{tabular}{ccc}
\hline lag & Q-Stats & p-value \\
\hline 1 & 0,06999899 & 0,7913383 \\
2 & 0,23158848 & 0,8906585 \\
$\vdots$ & $\vdots$ & $\vdots$ \\
17 & 21,50730265 & 0,2044166 \\
18 & 21,74616033 & 0,2434501 \\
\hline
\end{tabular}

Dengan menggunakan taraf signifikansi $\alpha$ sebesar 5\%, dapat dilihat pada Tabel 4 bahwa nilai $p$-value hingga lag ke-18 lebih besar dari pada nilai $\alpha=0,05$ yang artinya terima $\mathrm{H}_{0}$, sehingga tidak terdapat autokorelasi didalam residual model.

\subsubsection{Asumsi Heteroskedastisitas Residual LSTAR $(1,1)$}


Pada penelitian ini untuk mengetahui ada tidaknya efek ARCH/GARCH pada residual diuji menggunakan uji Lagrange Multiplier. Berdasarkan uji LM pada lag ke-18 dengan menggunakan taraf signifikansi $\alpha$ sebesar 5\% diperoleh nilai statistik uji, yaitu LM=14,769 dan nilai $p$-value $=0,6778$ lebih dari pada nilai $\alpha=0,05$ yang artinya data residual model LSTAR $(1,1)$ tidak terdapat efek ARCH/GARCH didalam residual model LSTAR pada lag ke-18 atau residual adalah homogen.

\subsubsection{As umsi Normalitas Residual LSTAR $(1,1)$}

Uji asumsi selanjutnya adalah uji normalitas. Menurut Rosadi (2016), uji normalitas tidak sepenting uji autokorelasi dan heteroskedastisitas sehingga apabila uji normalitas tidak dipenuhi model masih layak untuk digunakan. Uji asumsi normalitas dilakukan dengan menggunakan uji Kolmogorov-Smirnov. Berdasarkan uji K-S dengan menggunakan taraf signifikansi $\alpha$ sebesar 5\% diperoleh nilai statistik uji $\mathrm{K}$-S, yaitu $\mathrm{D}=0,4506$ dan nilai $p$-value $=<2.2 \mathrm{e}-16$ kurang dari pada nilai $\alpha=0,05$ yang artinya data residual model $\operatorname{LSTAR}(1,1)$ tidak berdistribusi normal.

\subsection{Peramalan dan Evaluasi Hasil Pe ramalan}

Ramalan nilai return untuk satu periode ke depan, yaitu:

$$
\begin{aligned}
\hat{X}_{412 \mid 411}=-1, & 781118(0,01011813)\left(1-\left(\frac{1}{1+\mathrm{e}^{-0,999998(0,01011813-0,046558)}}\right)\right) \\
+ & 3,275201(0,01011813)\left(\frac{1}{1+\mathrm{e}^{-0,999998(0,01011813-0,046558)}}\right)
\end{aligned}
$$

Hasil ramalan harga saham mingguan PT Bank Mandiri (Persero) Tbk untuk periode 01 Januari 2019 sampai 30 Desember 2019 adalah sebagai berikut:

Tabel 6. Ramalan Harga Saham PT Bank Mandiri (Persero) Tbk

\begin{tabular}{ccc}
\hline Periode & Data Asli & Data Ramalan \\
\hline $06 / 01 / 2019$ & 7725 & 7502,028 \\
$13 / 01 / 2019$ & 7700 & 7556,434 \\
$\vdots$ & $\vdots$ & $\vdots$ \\
$22 / 12 / 2019$ & 6975 & 7678,687 \\
$29 / 12 / 2019$ & 6400 & 7678,687 \\
\hline
\end{tabular}

Pada hasil ramalan model runtun waktu yang diperoleh akan dilakukan evaluasi peramalan menggunakan symmetric Mean Absolute Percentage Error (SMAPE). Nilai SMAPE menunjukkan angka yang cukup kecil, yaitu 5,12 \% sehingga dapat dikatakan peramalan dengan model LSTAR $(1,1)$ sangat baik.

\section{KESIMPULAN}

Kesimpulan yang didapat dari hasil analisis dan pembahasan pada penelitian ini adalah sebagai berikut:

1. Dari analisis dan pembahasan didapat model LSTAR $(1,1)$ data return harga saham PT Bank Mandiri, yaitu:

$$
\begin{aligned}
X_{t}= & -1,781118 X_{t-1}\left(1-\left(\frac{1}{1+\mathrm{e}^{-0,999998\left(X_{t-1}-0,046558\right)}}\right)\right) \\
& +3,275201 X_{t-1}\left(\frac{1}{\left.1+\mathrm{e}^{-0,999998\left(X_{t-1^{-0,046558)}}\right.}\right)+\varepsilon_{t}}\right.
\end{aligned}
$$

2. Berdasarkan hasil ramalan harga saham PT Bank Mandiri dapat dilihat bahwa nilai Nilai SMAPE menunjukkan angka yang cukup kecil, yaitu 5,12\% sehingga dapat dikatakan peramalan dengan model LSTAR $(1,1)$ sangat baik. Dengan nilai ramalan terbesar yaitu 
pada tanggal 23 Desember 2019 sebesar 7678, 687 dan nilai ramalan terkecil yaitu pada tanggal 6 Januari 2019 sebesar 7502,028.

\section{DAFTAR PUSTAKA}

Campbell, J.Y. Lo, A.W. dan MacKinlay, A.C. 1997. The Econometrics of Financial Markets. New Jersey: Princeton.

Chen, C. Twycross, J. dan Garibaldi., J.M. 2017. A New Accuracy Measure Based on Bounded Relative Error for Time Series Forecasting. PLoS ONE 12(3).

Dijk, V. 1999. Smooth Transition Models: Extensions and Outliers Robust Inference. Amsterdam: Tinberg Institute.

Hyndman, R. J. dan Khandakar, Y. 2008. Automatic Time Series Forecasting: The forecast Package for R. $3^{\text {th }}$ Edition. Journal of Statistical Software. Volume 27.

Rosadi, D. 2016. Analisis Runtun Waktu dan Aplikasinya dengan R. Yogyakarta: Gajah Mada University Press.

Santoso, R. dan Sudarno, S. 2017. Metode Nonlinear Least Square (NLS) untuk Estimasi Parameter Model Wavelet Radial Basis Neural Network (WRBNN). MEDIA STATISTIKA 10(1) 2017: 49-59. DOI: 10.14710/medstat.10.1.49-59.

Terasvirta, T. 1994. Spesification, Estimation, and Evaluation of Smooth Transition Autoregressive Models. Journal of the American Statistical Association. Volume 89, 425.

Tsay, R. S. 2010. Analysis of Financial Time Series. Edisi Ketiga. Kanada: John Wiley \& Sons.

Wei, W.S. 2006. Time Series Analysis: Univariate and Multivariate Methods. $2^{\text {nd }}$ Edition. USA: Addison Wesley.

Zubir, Z. 2011. Manajemen Portofolio dan Penerapannya dalam Investasi Saham. Jakarta: Salemba Empat. 